\title{
A. Karskens
}

Pleisters op de ogen, pleister op de mond. De Nederlandse oorlogsverslaggeving van Heiligerlee tot Kosovo

Amsterdam (Meulenhoff), 200I, 376 p., f 45,I8, ISBN 90-290-69-12-0

Waarheidsvinding is een groot goed, maar is het ' $t$ leven van een journalist waard? Ziedaar het dilemma van de oorlogsverslaggeving, de meest fascinerende en tegelijkertijd meest gevaarlijke specialisatie van het journalistieke bedrijf. Oorlogsverslaggeving is een tak van sport die een behoorlijke dosis lef vereist, en dan nog is het resultaat soms minimaal. Want het vergaren van informatie onder de moeilijkst denkbare omstandigheden leidt er nogal eens toe dat de waarheid het eerste slachtoffer is. En als de oorlogsjournalist niet oppast, is hij het volgende.

Het spreekt vanzelf dat iedere verslaggever die zich welbewust naar een oorlogsgebied begeeft om het thuisfront te informeren over de gebeurtenissen aldaar, van plan is om terug te komen. Het liefst met een onthullend verhaal. Maar kan al bij voorbaat niet worden vastgesteld dat zijn missie een onmogelijke is, vol persoonlijke gevaren en professionele valkuilen? Zijn de omstandigheden niet altijd te gevaarlijk, te chaotisch, te onoverzichtelijk en te emotioneel om het werk correct te doen? Staan de extreme aard van het onderwerp en de te hanteren, strenge journalistieke normen van volledigheid, onpartijdigheid en zorgvuldigheid niet haaks op elkaar?

Arnold Karskens, zelf oorlogsverslaggever met een lange staat van dienst, ging op zoek naar de zin van de Nederlandse oorlogsjour- 
van het vak. Hij schreef zijn bevindingen op in Pleisters op de ogen, pleister op de mond. De Nederlandse oorlogsverslaggeving van Heiligerlee tot Kosovo. Subjectief uitgangspunt was de vraag of de vaderlandse oorlogsverslaggevers uit het verre en recente verleden hun werk 'naar behoren' hebben gedaan. Het manco van dit boek ligt, vanuit geschiedwetenschappelijk oogpunt, dan ook voor de hand. Karskens bekijkt de geschiedenis van de Nederlandse oorlogsverslaggeving met een praktische blik en een maatstaf van hedendaagse journalistieke normen. De voorspelbare uitkomst: het was zelden goed (genoeg).

De auteur hanteert een scherpe pen en spuit zijn kritiek volmondig en fel. Hoe meer hij de eigen tijd nadert, hoe meer hij het geschiedschrijven loslaat en subjectieve analyses maakt van het werk dat de Nederlandse oorlogscorrespondenten produceerden. Persoonlijke aanvallen schuwt hij daarbij niet. Zijn beschrijving van de zeer recente persgeschiedenis is zelfs verworden tot een aanklacht tegen het handelen van het Nederlandse journaille in conflictgebieden en een gericht pleidooi voor professionelere oorlogsverslaggeving.

Daar is op zich niks mis mee, maar wel als het is verpakt als geschiedschrijving. En de felle toon waarmee het functioneren van collega's door Karskens ter discussie wordt gesteld, ontsiert het boek ook. Want hoewel de journalist-schrijver op veel punten gelijk heeft (er zijn belangrijke historische lessen te leren, juist omdat er in deze vorm van verslaggeving levens op het spel staan), weet hij dat niet overtuigend over te brengen.

Kijkend naar de aard van het vak is het de vraag of het terecht is dat Karskens de toga van scherprechter heeft aangetrokken. Ten eerste omdat de oorlogsverslaggeving één van de moeilijkst denkbare beroepen is, zodat best wat begrip mag worden opgebracht voor de fouten. Ten tweede omdat in andere tijden andere waarden en normen golden. Natuurlijk waren de verslaggevers van vroeger bij tijd en wijle volgzaam, partijdig, nationalistisch, laf, onprofessioneel volgens hedendaagse normen, niet kritisch en gemakzuchtig. En natuurlijk hadden hun verslagen soms weinig meer met journalistiek te maken, werden feiten verzwegen en werd propaganda bedreven. Grotendeels zijn dit pershistorische open deuren.

Want: voordat Karskens aan dit boek begon was het grootste deel van bovenstaande 'misstanden' al bekend. Ze gelden voor de Nederlandse journalistiek in het algemeen, en ja, nu blijken ze ook de oorlogsjournalisten 'aan te rekenen'. Dat is geen verrassing, en het is vooral gemakkelijk, maar niet constructief, om achteraf met het vingertje te zwaaien.

Misschien was de gehanteerde vraagstelling vanuit historische oogpunt dus niet zo slim. Wie de Nederlandse persgeschiedenis sinds 1618 een beetje kent, had met Karskens' manier van werken op voorhand de antwoorden kunnen bedenken. Bovendien: harde lessen trekken mag, maar ze verminken tot verwijten is fundamentalistisch. Beter was het misschien geweest als de schrijver de lessen sec had getrokken. Het anachronistische denken, een wetenschappelijke doodzonde, had dan achterwege kunnen blijven. Het resultaat was echter nagenoeg hetzelfde geweest, en Karskens had dat neutraler kunnen opschrijven. Dat had een degelijker boek opgeleverd, en het had de conclusies over het gezochte nut van de oorlogsjournalistiek treffender gemaakt. Bovendien had het de lezer de betweterige toon bespaard, die nu op iedere pagina als achtergrondmuziek aanwezig is en die zo nu en dan (zeker op het einde) aanzwelt tot een kakofonie.

Maar het zou oneerlijk zijn om dit boek uitsluitend te beoordelen op de aanpak. Karskens onthult namelijk verdienstelijk de valkuilen en gevaren van de oorlogsjournalistiek in het algemeen en de lessen uit de Nederlandse geschiedenis in het bijzonder. Pleisters op de ogen is daarnaast een boek vol leuke wetenswaardigheden en goede anekdotes. De auteur weet hoe hij een verhaal moet vertellen en houdt de aandacht vast. Dat het niet allemaal even 'wetenschappelijk' is wat hij schrijft, neem je op de koop toe. 
Het feit dat het geheel op een vlotte wijze is opgeschreven, heeft juist een ontnuchterend effect. Weliswaar velt Karskens harde oordelen en speelt hij soms wat al te erg op de persoon, toch is de boodschap duidelijk. En die mag ook mediaonderzoekers niet ontgaan. Zij hebben immers echt iets aan de wetenschap dat de beelden en teksten van de oorlogsverslaggevers van weleer veelal onbetrouwbare bronnen zijn.

Er is nog een ander voordeel van Karskens' ontmaskering en ontmythologisering. Het maakt zijn boek namelijk tot verplichte kost voor studenten. Jonge journalisten-in-de-dop worden op de opleidingen begeesterd met de stoere verhalen van oude knarren. De journalistiek is nu eenmaal een beroep van sterke verhalen. Naar het journalistieke metier is echter minder onderzoek gedaan dan er autobiografieën over zijn verschenen. Dat behoeft wederhoor, en die van Karskens is ronduit ontluisterend. Conclusie: dit is een goed leerboek voor de studenten aan de scholen en opleidingen voor journalistiek die de ambitie hebben om in Karskens' voetsporen te treden.

Arthur ten Cate 